Portland State University

PDXScholar

\title{
The Study of the Differential Effects of Visual and Auditory Presentation on Logical Reasoning
}

Jacob Lauterstein Driesen

Portland State University

Follow this and additional works at: https://pdxscholar.library.pdx.edu/open_access_etds

Part of the Psychology Commons

Let us know how access to this document benefits you.

\section{Recommended Citation}

Driesen, Jacob Lauterstein, "The Study of the Differential Effects of Visual and Auditory Presentation on Logical Reasoning" (1977). Dissertations and Theses. Paper 2551.

https://doi.org/10.15760/etd.2546

This Thesis is brought to you for free and open access. It has been accepted for inclusion in Dissertations and Theses by an authorized administrator of PDXScholar. Please contact us if we can make this document more accessible: pdxscholar@pdx.edu. 
AN ABSTRACI OP THS 2HESIS OP Jecob Lauteratein Driesen for tho Master of Sclcood in Pajcholog precented Pobruny 10, 1977.

Iitles Difforantial Bffects of Visun and Auditory Presentation on Logical Reasanting:

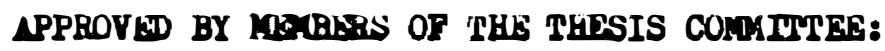

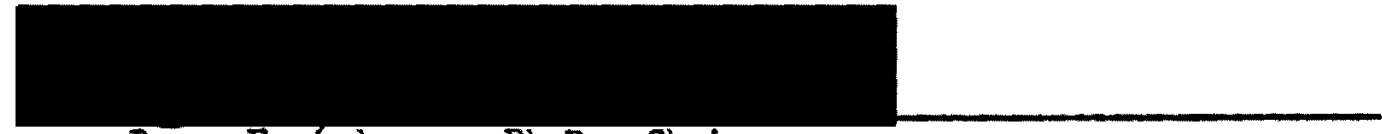

Berry F. Anderson, Ph.D., Chairnan

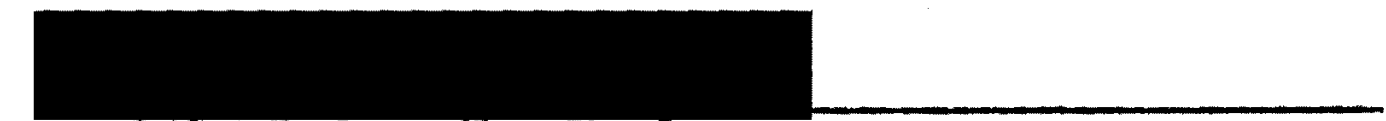

Robart L. Joned, JI., Ph.D?

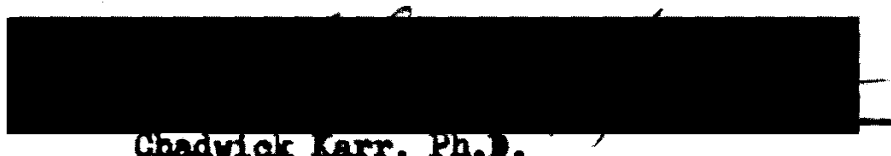

Ghandar Larr, Ph.J.

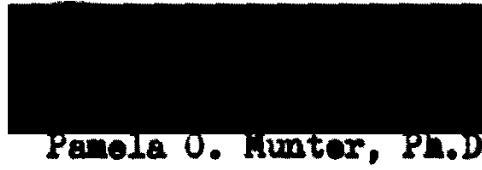

A fundarental taak in reasoning is to for sose intermal representation of the premlees that allowe the rolations between them to be determined. Whother this process is visual or auditory is the subject of a long-stending controverey (Desoto, 1965; Clark, 1969).

'l'his controverey neens to have resched a stalonate. Anothor approsch is to doternine where in the bratn ressoning is dono. A way of doing this 1070 ives looktng at difformon in tho procesaing and storage of vioual and auditory inforation within tho bratn. Brooke (1967) unod this approach in h1s orperinonte. His rosults eusegested that a subject who recoires opatiel inforation by way of tho ear will, concurront ifth rocoption, convert it into a vioun roprocontation. If, howerer, the individual rocoives a noseage in written fore, bo must woe tho vioun ojoten to both idantify tho words and, at the eane tino, ropresent the opetial relationahips. Viounly roceived messages interfere with the generation of internal ropresentations of epatiel rolations. Later experiments convinced Brooks that nemorles are otored in the oysten by which thoy onter tho bratn.

Our pilot atudy involved the visual and auditory prosentation of 16 ayll- 
ordeng to two groupe, each ooppriecd of ten randonly selected subjects. Tho ade tenk was to doteralne the validity or lnvalidity of each oyllogien. In addition, a menory tack res prosanted, in which one part of each of elfht of the orfiginal wa ahown to each oubject and the oubject then had to recall the two desing parte. Resulte Indicated that anterialo recelved vis the ear vere nore effectively proceseed then those received by way of the eye ( $<.005)$. The ouditory group did better than chance $(p<.05)$, whlle the vioual group did more poorly than chance $(p<.05)$. Besentially equal anounte wore rotatned in nenory, but the abllity to eolve the problen correotly wes highly correlated with sovory only in the auditory condition ( $r=.796, p<.005)$. This did not hold in the vioual condition (I=.059, R.0.). The difference between the two correlation coofficlente was significant $(p<.05)$.

The eocond apperinent mas essentially ldantionl to tho pilot otudy, with the only eajor changes bolng the use of ten oyllogleas and a nenory teak of

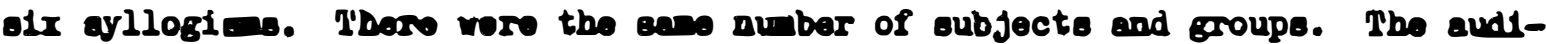
tory broup vas agats the sore ouccesaful $(p<.005)$. Tho auditory broup did botter than chance ( $p<.02)$, whtle the vieusl group did aro poorly than chance $(p<.01)$. SBein menory was essentielly equivelent, but tho corrolattone botween tho logic tank and anary task was .80 (p<.005) for tho aud1tory group wille it weo but .022 (n.8.) for the Flous group. The difference botwoen those tro flgures was ofenifloant ( $p<.02)$.

I'bo rooulto of our otudy tend to oupport an inger theory that the Interw a representations involved in oyllogletic reaconlng are Noun in nature. Brooks' logic nost noarly erplates the poor chouting of tho visual groupe in

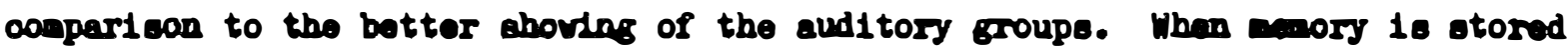

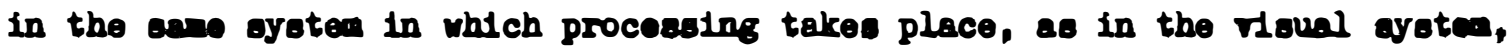
then you would expect conflict and a lover level of performance.

'Lhore 1o alé nouropababologlcal oridence to support an Image theory (Lur-1a, 1973). 


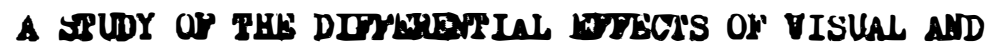
AUDIPORY PRESSWMAPIOA ON LOGICAL RBASON DNG

\author{
by \\ JACOB LAUTLRSTEIN DRIRSTES
}

A thosis oubatted in partial fulfillnant of tho requiremants for the degree of

mastegh or scivaci

in

PSYGLOWOY

Portland State Undreraity

1977 


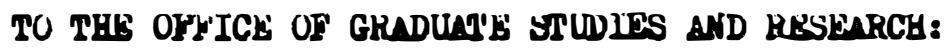

2he nembers of the Coamsttee approve the thosis of Jecob Lauteretein Driesen presented Pobruary 10, 1977.
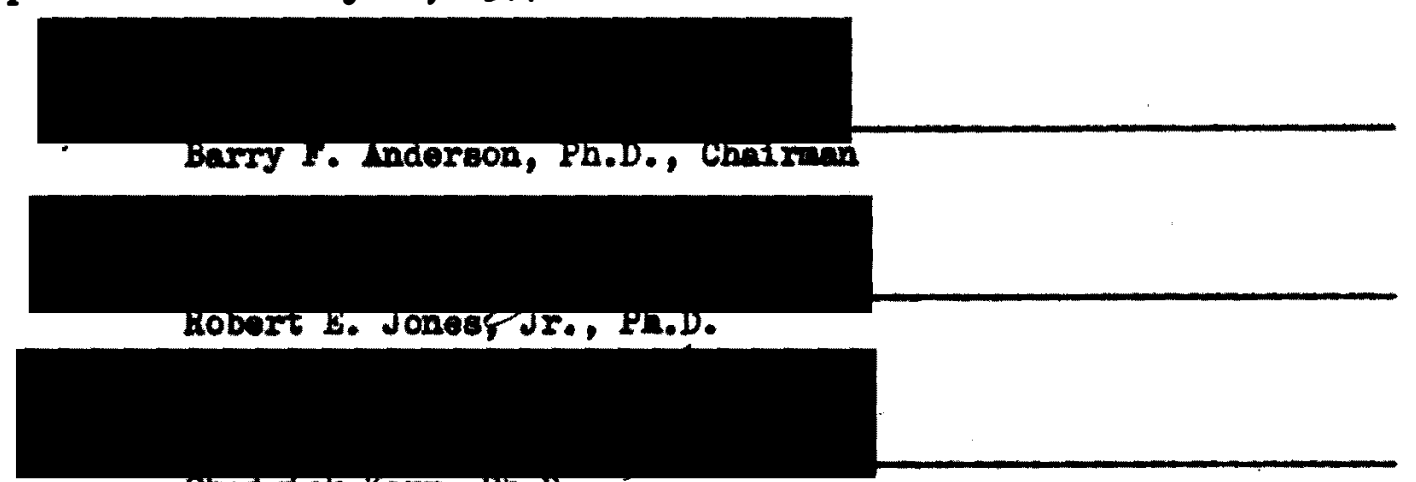

Chadrick kars, Yh.D.

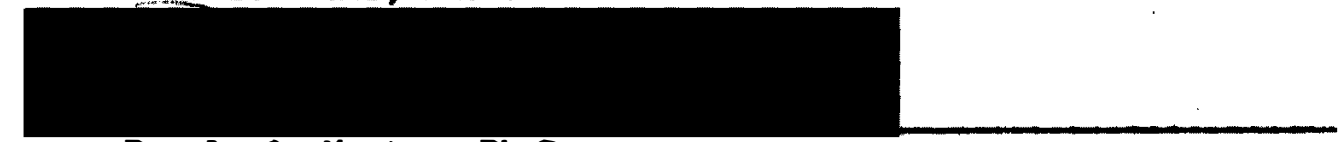

Panela 0. Munter, Ph.D.

\section{APPROVHD:}

David L. Crocalor, Ph.D., Head, Dopartment of Paychology 


\section{ACROULEDGEYRTS}

It is to ay parents that this thonto is dedicated. Thyy encouraged ao froe the baginning and it 18 due to tholr love and thoir support, both emotional and flnancial, that this project has boen conploted.

My love and epprecietion aleo 60 to a vifo, Jual, for har love, undor standing, and patienoe during this projoct.

Special approciation coes to a frlend Bary sndereon for all bo has done for and for the sreat esounte of time bo opent bolpling ao and encourar-

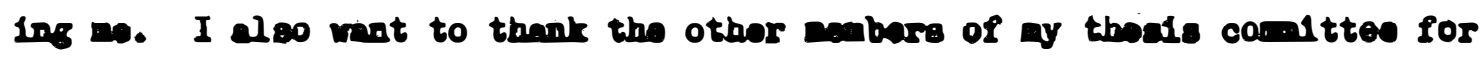
their advice and eactetenoo. 


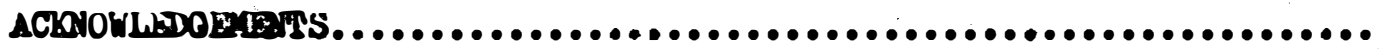

CHAPILR

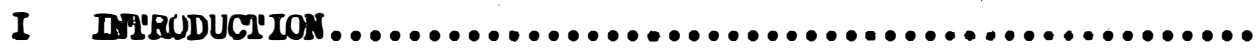

II THE SIUDY...................................

Bsporinont 1..................................

Experzinat 2................................ 5

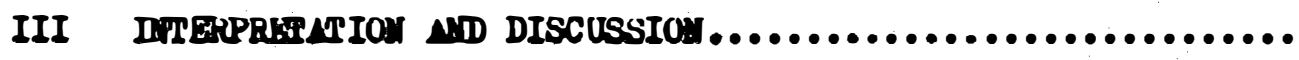

Iv corcubsions......................................

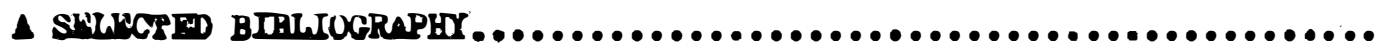

$\triangle P P E D I X$ X $1 \ldots \ldots \ldots \ldots \ldots \ldots \ldots \ldots \ldots \ldots \ldots \ldots \ldots \ldots \ldots \ldots \ldots \ldots \ldots$ 


\section{CHAPE퍼 I}

IIPRODUCEION

1 fundamental leak in reasoning is to for 8050 internal representation of tho prendees that rill allow the relations botween then to bo deternined. There has been a oontrovaray for con tine as to wother this procese is visunl or auditory.

Desoto (1965) conducted a serles of expersnote concersed with tho or

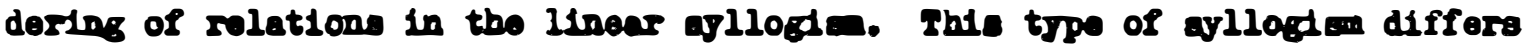

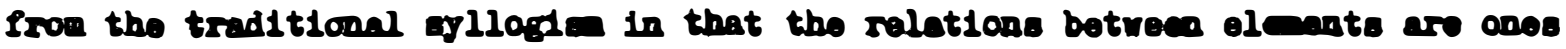
of order rethor than of Incluaton or 1oplication. For eranples

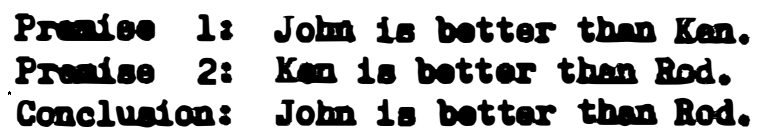

A phenmon that has been noted 10 a tendeney to treat a given eot of

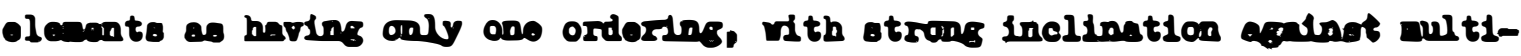
ple orderinge of tho sane set. Tbough provious experchete (DaSoto, 1961; Sampeon, 1963) fatled to reveal any cluo as to the internal prooveses involred, Desoto (1965) feols that his later work and explate the phenosenoo.

H1. arplenation 10 that people are good at thiniding of elenents as ordered because they can easly arange ener approprlately on an exde. But, tho ads 18 ans one-dimonatongl. I'bus, elthough a person oan order people by appearance, bo cannot alnultaneoulf order the by age. He foels this 10 why worde 11 ke "hteg" and "low," and "above" and "bolow," have a tremendous sange of motaphorion meanings.

Desoto belleres that people work on these aros fron top to botton and

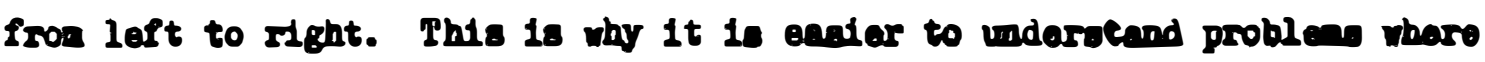
"greater than" cones before "leas then," rathor than the roverse. Thus, Desoto seed logical thoucht as conslating of construoting opatial rolationghipe. Wo w11l oall this the Inage I'beory of receoning.

$\Delta$ problew tho Inage Theory cannot hadie 1o that probleas involving "deeper" and "ahnllowar" aro not colved as prodloted. It 1o faster to undar-

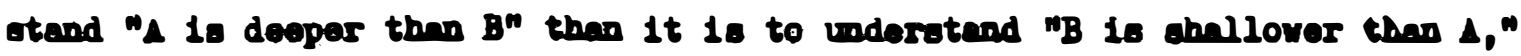
(Clark, 1969). Th1s 10 so deaplto tho fact that in translating "A 18 doeper than B" Into an Inge, we would plase B above A on tho arde and than wort dom fron top to botton. 
Beasd upoo this inconsiotenoy, Clart (1969) conducted a ser1es of expericonte that ho bolieves show that reasonlng 18 accoppliebed aninly through

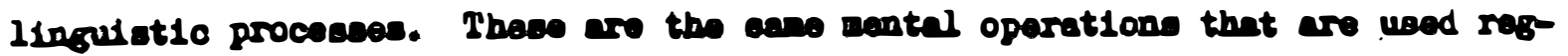
ularly in underatending 1naguace. Clark ang that in order to oolve the "deepar" and "ahallower" problen, wo wat use ledenl nardings.

One way of exproeslng the relationains (for exn-ple, Freater than, deopor than) 18 called unated and 18 considored to be fundenental. Tho other was (for eraple, less than, shallowar thon) 10 colled antred and 18 cupposed to be dartived froe the unneted form.

In oupport of this 18 the finding that ahdldren understend unarked

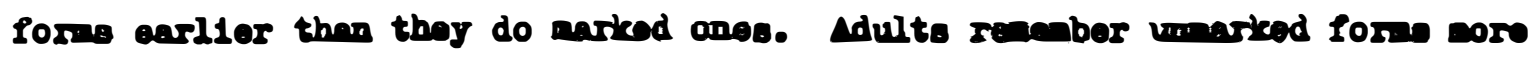
easily. Neo, tho unarted form can nan a poattlon on tho scale or tho whole soele 1taelf, whle the raried form can ano poattion only. Thu, if you aak For old 1s chop" aho could be elther young or old. If, boverar, you ask Fiov young 10 shop" you aro loplying abo 1s yourg.

The thoory we will call tho Inoulatic Thoory prodicte that tho unarted

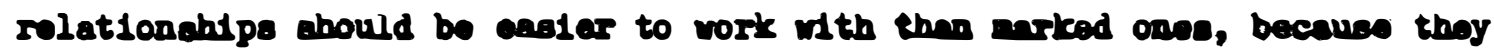

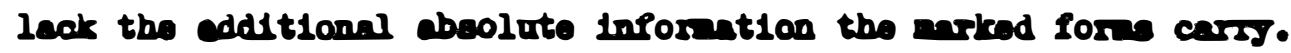

Thu "deeper than" Inplies a scele, while "shnllower than" appeare to describe just a position on the ocale wo call depth.

But, Clari's thoory does not elways predict correctly elthar. For er-

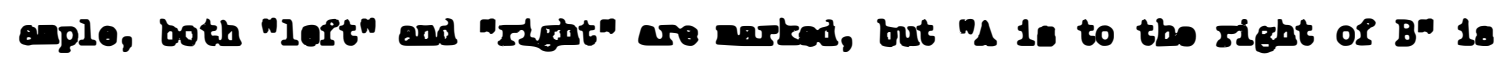
casier to underotand then "B 18 to tho left of $\Lambda_{0}$ " Clart cannot anovar this parador.

The DeSoto - Clark controveryy secas to hare cose to a otalenate. $\Delta$ -

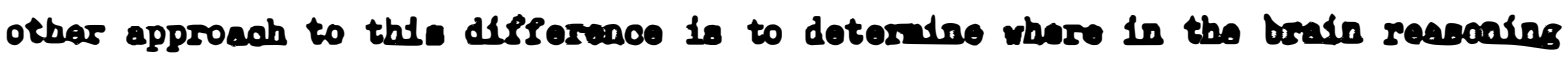
18 dose. One way of dodeg this involves looldng at differveces in the proceseIng and otorage of Flawal and audstory inforation withs tho bratn. Conparlsons of this asture would be clearly be relevant to the Inage l'boory. Whothor thoy would be relevant to the hiogulatic Thoory vould depend an whother one 18 villing to eseume that linguibtlc proceseos aro easentially auditory.

Brooke (1967) onryed out a ser1es of eppersnents using this approach. He uppothosised that a oubject who recelves opatiel lnforention rerbally w1ll, concurrent with rocoption, convart the asaage into a Vioun roprosentation. Thus, tho rioul syoten 10 partialy ocoupled during this proooce. If, how over, the Individun recelfee tho soscage in a reltten forn, bo wat use tho 
Founl aroted for two purposese to ropresent tho opatial rolationatipe and to Identify the vitten wordo. If, then, thare 18 8000 orerlap in the eachaniems

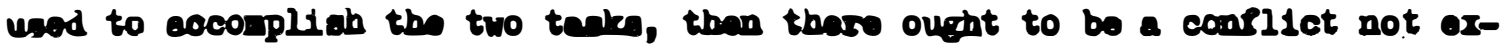
parleneed when the noseage 10 hand.

H18 cubjects varo presented vith opat1el aeseages both Flaunlo and

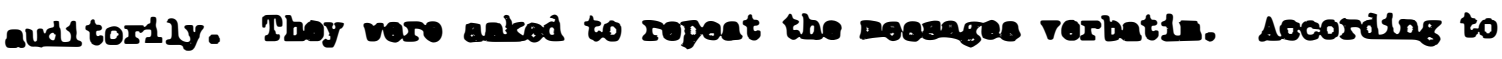
this thoory, tho hoering croup ahould do better than the vioun croup, alnoe

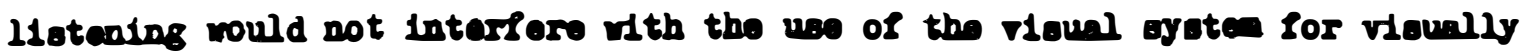
ropresenting the secsages. To prealude tho precence of factore blesed against

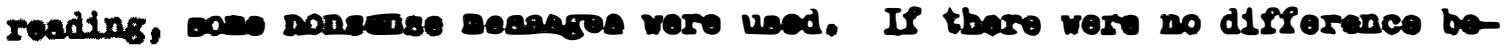
twoen perforance arter reading and performance after llatening vith noneense

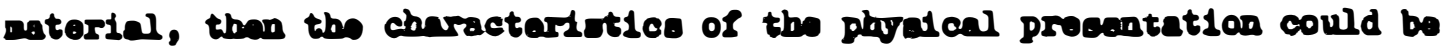
elininated as a oufflalent explanation for tho roculto wth tho opetial loforntion.

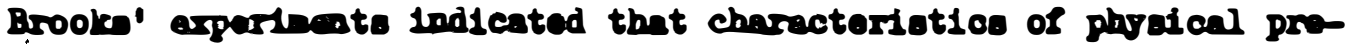
sentation are not involved. What does eeen to bo happening 10 that the v1oualy

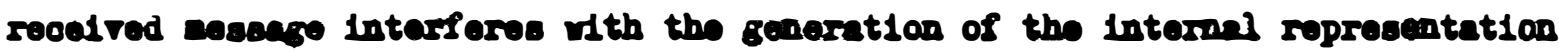
of the opatial rolationo.

Brooks (1968) in a corses of experinate found that rocall of rerbal information 10 not roadily di arupted by concurreat vocal activity. Rocall of opatial inforetion wer found to bo noot readily diarupted by concurreat opatialy andtared cotiflty (for eraple, writing). Brooles concluded that

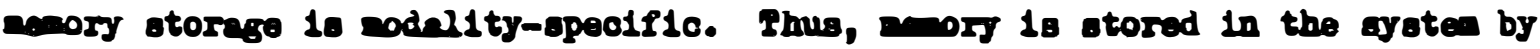
which 1 entore tho brain. 


\section{GHPIER II}

\section{TIS STUDY}

In an affort to shod sose llebt on tho Clark - DeSoto controveray we declded to cosduct experinants deaicond to lake advantage of the conclusions Brooto derived from his otudiea. We felt that by uaing his technique of both auditory and Noun prosentation and conbining it vith oyllogien es verbal otinulus aterials, we nifent be better able to deterndoe the form ropresentatione teke during the ressoning procese.

\section{EसPसमITIT 1}

Thio pllot study involved the v18un and auditory presentation of oylog1ens.

Subjects vere twenty male and feanle unfreraity studente vth an ago range of 18 to 50 geare. Thoy were randond difided into two groups of ten each. Group I recolved the otioull visually, each ayllogion typed on a separate 3 X 5 plein white card, and being road once by each oubject. Group II recelved the oflloglans vie the ear fran a provlougly recorded tape. Subjects beard each ayllogien once. Beab oubject beard or read a total of 16 Byllogiting, all rocolving tho sano ones.

Tho subjects' tack was to deterine whothor ach aylloglen was vald or invelid according to tho rules of logte which were explained to then as folLOwB:

This 18 a test in roaconsh8. You are to indlcate for anch of the folloving argemente whtoh are "sound" and which aro "unoound." I "8ound" argunent 18 ane in which tho concluation follows loglcelly from the pre1808. The rord "al" in loglc means eech end every cape. "Son" mans

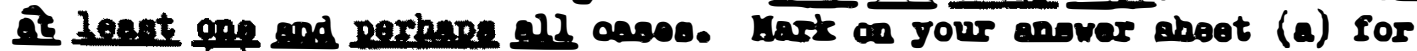
sound or (b) for unsound for each eroment.

ster comploting judpants for al 16 wllogden, a nenory takk followed. Une part of each of elent of the orfofinal 16 ayllogiang was preacented, and the subjects ware aaked to recall and record tho renaining two parts. Bract wordformord recall was not required.

Hesulte inaleated that conplex rerbel material recelved vile tho our is more offectively processed than that received via the eye (Group II, $\bar{z}=10.00$,

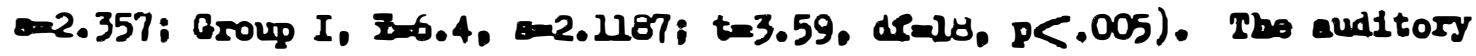
Eroup, Group II, correctly Judfed an averege of 62.5 per cout of the ayllogien. 
Thle was olonsicantly bettor than ahance (t-2.68, df-9, $p<.05)$. Tho Vloual group, Group I, correctly judiged but 40 per oent of the ayllogden, aloniflcently poorer ehno chnoce (t-2.39, dr $99, \mathrm{p}<.05)$.

Although oseontielly equal mounts rare recelled fron nesory (Group II,

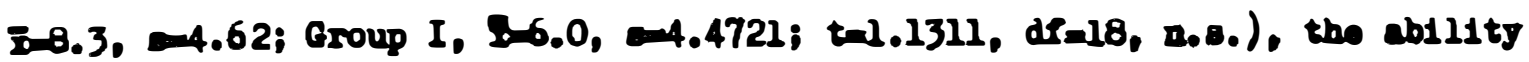
to solve the problea correctly vas hichly cosrolated with weingry only in the auditory condition. Tho corsulation botween the nubar of corseot logic judgente and the totel anut rocalled was equal to .796 (t-3.72, df 8 , $p<.005)$ in tho avditory croup. This did not bold in tho vlousl oondition

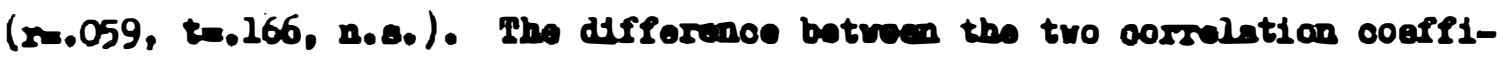
clente was itaele aleniflant $(s=1.89, p<.05)$.

\section{Expanis 2}

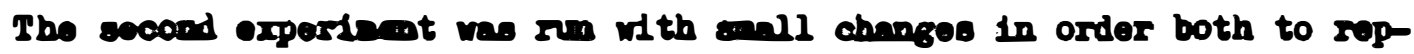
licate the pllot otudy reoulte and to refino the analyale of those resulte.

Treaty ale and fonle univaradty otudente waro used with an ago rango of 18 to 30 years. Those cubjeots, diffarent individunls then those in the pilot otudy, ware rendonly difldad Into tro groupe of ten cach. Tho tantes vore Identicel to those in tho slret otuds.

Inotead of 16 gllogien, tea waro presented, while tho nory tenk in volved als of those tea. Soe 4 ppendices 1 and 2 for thoee.

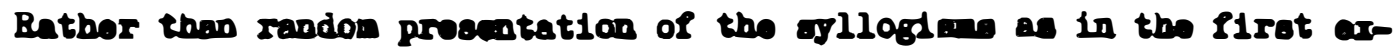

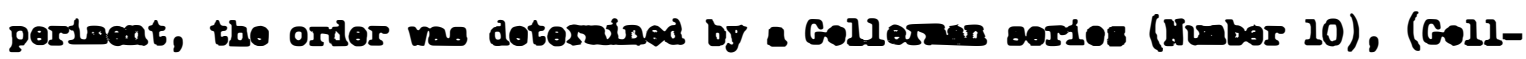
erran, 1933), which was dealened to nininise the posalbillty of solving tho probleng at botter than chance level (5 correct) by fornting oifple otraterdea based on order of presentation.

The auditory sroup (Group II) again did botter than tho fioual (Group I) (Group II, I-6.0, 0-2.0541; Group I, I-3.5, e-2.4357; t-4.44, df=18, p<.001). The auditory group oorrectly juifed 60 por cent of the oyllogide, whioh was oiconificantly beotor than chnnce (t=3.16, drm, p<.02). Tho vioun group correctly judged only 35 per cent of the aylloglen, which was olfonificantly poorer them chance ( $t=3.31$, df $=9, p<.01$ ).

The correlation between performance on the logic tegt and the enory toot was equal to .80 (t-4.25, df $-8, p<.005)$ for tho eudstory broup, while it was oqual to .022 (t..061l, n.8.) for tho Noun sroup. Tho differabos betroen

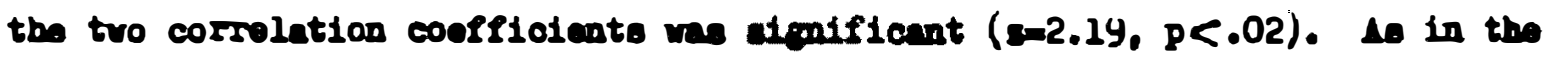


pilot study, both croups retained equivelent arounto in meorg (Group II. s.5.9, s-1.45; Group I, s-4.9, ol.79; t-1.37, n.8.).

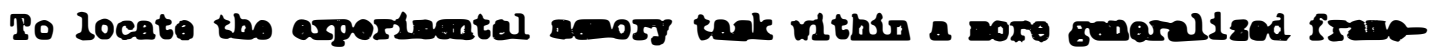
vork, it would seen that It lavolves long-ters rather than short-ters memory and ceanntic rathor then opleodic ecoorg.

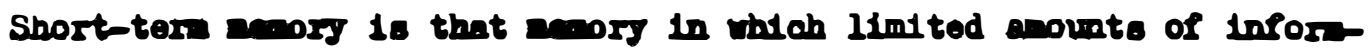

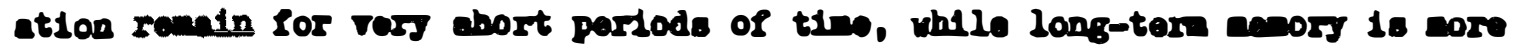

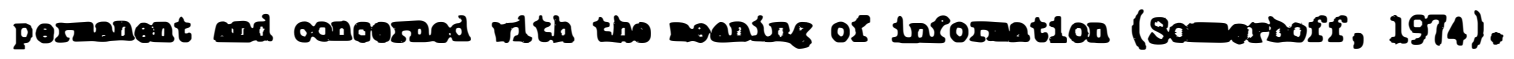

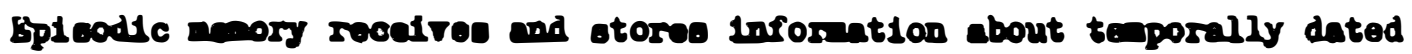

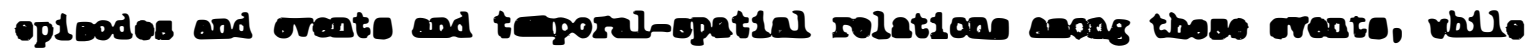

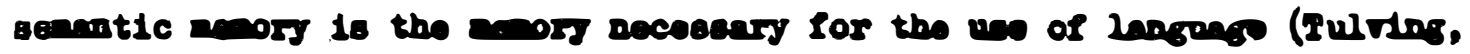
1972). 


\section{CHAPPER III}

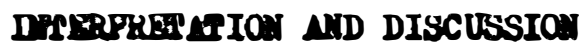

Tho roaults fron our study tand to support an inage thoory, thoweh not necesearly DoSoto's. Such a thoory would bold that loglen reasonthe is a opatial takk taling place in tho visual aysten.

Tho difference botween tho parfornanoe of tho auditory and vibual croups in both experiente can bo explesinod by Brooks' logic. Tho probable explanation for the poor performece of the visual sroup is that lnooning infornetion via the oje interfares with the orderly conferetion of the interen reprosentation of tho prenseas in tho visual aysten.

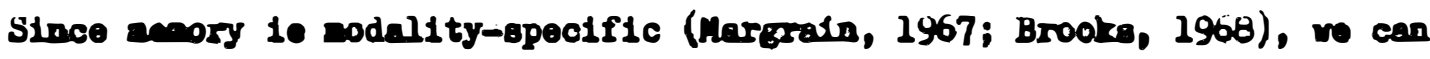
800 that aesory stored in the viaual ojaten, while equivalent to the anount in tho auditory aysten, 18 less apoeseible for orderly use beceuse of confuaion Ithin the visual ayster.

Phus, what appoars to bo happensing is that although essentially equal amounts are retained in recory, tho visual croup finds it difficult to apply thls stored infornetion to tho colution of tho problen. In easence, then, ecebers of the visual croup aro making thotr logical dociolone on factors conneoted rith recall of the stored Infornation. Ifolr perforence at a lorel well bolow chance would 1ndicate that they are not gueseing per se, but aro aking decielons via another thinkting process; a procese that 18 lese oucceserul than gresoing.

Thore 18 nouropejchological ovidence that provides additional oupport for an Inge theory. Lurla (1973) deccrlbes patients with lestono of the parieto occipital region of the dominant healephare, a roglon adjointing tho vioun aseociation area. Thees patiente understend everyday narrative perfectly voll, but find it difficult to understand whet Lurle cells "conplex logkcal-framstical" structures. Por ernple, whlle thay are vell able to underatend narrat1ve speech ('mother and father went to the store, but Jane and Dick stayed bos.'), thoy cennot understand a sentenoe incorporating conplex logloal-gram atical relationabips ('a ean cene fron the off1ce to tho school where Bobby was a student to give a talk'). bren with ouch a stople sentence as 'tbore 18 a b1n's neat on the branch of the tree' confused thoee peple. They were unable to understand the rolationship betwoen the words brench, tree, nost, and bird. 
Purthor regearch by Luria has indicated that patients wth lesions in this area of the brate find basic adels of ayntactic otructure dealing with losicel relationehipe Incomprehemalble. He thus differentiates botween "cornunications of rolationahipa," and "comunications of ereats." In abort, patiente suffering from those leatons in ano of tho most developed part of the neocortex, find analyaie of sybolic aterial difficult or inposaible. IhIs does not hold for danage in tho parleto-occipital region of the nondoulnant bendephore.

In even wore oompelilng diecovery is a genorel feature that Luria finds in peoplo ouffering these perieto-occipital lesiono. I'hoy cannot find thoir bearings within a ayoten of opatial coordinstes, and thoy can no longer dietingutioh richt sron left.

Luria's nouropucholorden findinge vould soem to oupport the 1 dea that reasoning io patial in forn, as his pationto with parioto-occipital lealons of the dominent heiisphero aseociated with opetiel procoseing 1080 the ability to reason logically. This mould, of coures, be in direct opposition to the Lingrietic Thoory of Clark.

It ahould be soted that the bind of reasonlng we are discusaing only appease in the fornal operations stage of dovelopaent. Thus, joung chtldren could not be expected nornally to colve those kind of conplex verbal problen, (P1aget, 1952). 


\section{CHAPER IV}

\section{CONCLUSIONS}

I'bo ovidence fron this otudy would tend to oupport tho idea that logicel reasoning is a opetial process taking place within tho Vlounl aystem (Brooks, 1967: DeSoto, 1965: Lurle, 1974).

However, DeSoto's work was done with unprectleed abjects, as was ours, while Clark worked with practiced aubjects. In area of investigation for tho future would be to deterine if we visulise probleas until we have developed a otratecy for solution that would allow w to dael with like problens on a purels verbel beals. Clerk (1969) and Wason and Jobnson-lated (1972) have aregested this posaiblitity.

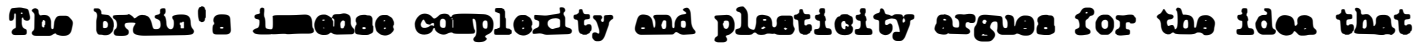
any conplex nentel procoseos any not bo atatic in phyaleal location or process, but an chnnge du to expariceoc and to tho needs of tho orgenter.

un analogy can be dravn betreen this and certaln bindo of notor activity. Compler notor activity, such as cating or plajing colf, at firat is processed at tho sotor atrip. Durles this atage the cerobollu mantore, and than pro grans the sovenents. With practice, the sovenemts are autonaticised. brentunly, when tho indifldun deoides to eat, tho cerobolll processes the novemeate, leaving tho corter free for noro novel and conplex noode (Mnr, 1969).

1 like land of process as occur in reasoning. Itho auditory system may Berre a role andagous to that of tho cerebellum in the notor aystem. This, than, would leave the viounl ayaten evailable for the solution of new and novel ldide of problens.

Studles involving the degres of prectice, as well as experience rerous non-experlence, would 80 far in bolping to understand tho basic proceseas. Anothor otudy for the future would bo the clasalflestion of different reasoning problen in cocordance with Guilford's stucture of intellect nodel. His waten cleasfieo intollecturl factors acoording to content, product, and

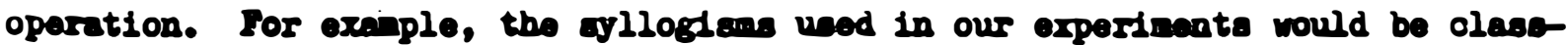
Ified as convergent production of roletions with sementic content, and the nemory taak would bo claseified as nenory of rolations with senantic content. Our atudy ouggeats that tho latter is not differantially affeoted by verbel ar arditory prosentation, whle the foreor 18, (Guilford, 1967). 


\section{$\triangle$ STLBCTED BIBLIOGRAPHT}

Mnoov, M. H., Kodeling of Thiniding and the Kind; Spartan Books, Now York, 1967.

Anderaon, Barry P., Comitive Parcholoxy Acadeatc Prese, Now York, 1975.

Brooks, Lee R., Tho suppreanton of vieunlication by reading., Qunet. J. exp. Prrahol., 1967,19,4,289-299.

Brooke, Loe R., Spatial and rarbal copponents of tho act of recall., Canad. I. Prychol., 1968,22,5,349-368.

Celder, Nigel, The ktind of kng; The Viking Prees, Now York, 1970.

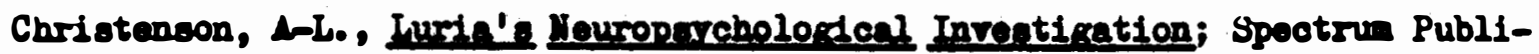
catione,Hew Yorte, 1975.

Clerk, Herbert H., Wrouletic processes in doductive reasoning., Parchol. Rer. , 1969,76,4,387-404.

Desoto, C. B., The predlliction for atsele ordaringe, J. Abnorr. Soc. Parchol., 1961,62,16-23.

DeSoto, C. B., Sociel reasoning and apatiel pardogic., J. Pere. Soc. Paxchol., 1965,2,4,513-521.

Gellexnan, Loula W., Chnnce ordere of elternating atinull in vioun diecrinination experinents., J. Genet. Parahol., 1933,42,206-208.

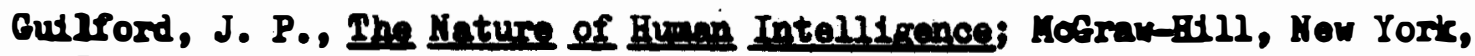
1967.

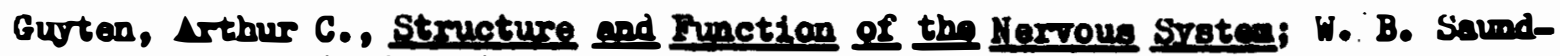
ero Conpan, Philedelphia, 1972.

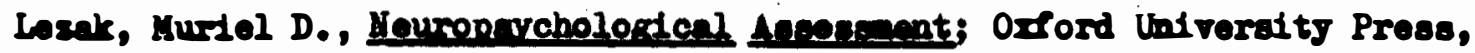
Nor York, 1976.

Luria, A. R., The Workding Britg; Basic Books, Now York, 1973.

Mareraln, Susan $\Lambda_{0}$, Short-tar acery as a function of input aodality., Quert. I. 9.7. Provehol.,1967,19,109-114.

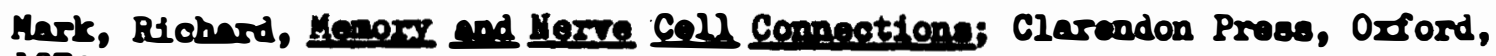
1974.

Mars, D., 1 thoory of corobollar cortex., I. Phratol., 1969,202,437-470.

Mathows, W. B., od., Becent Advencen in Clinteal Heurolorr, Vol. 1; Churahill Livingatone, vdloburoh, 1975. 
Plaget, J., The oxicine of Intelliagee In Childxen; International Univoraity Pross, Mex York, 1952.

Rose, Steven, The Conscious Brain; Alfed A. Koopf, New York, 1973.

Sempeon, B. D., Statur congruence and comitive conalotenoy. Socionetry, $1963,26,146-162$ 。

Somerbolf, Gerd, Ioric of the Living Brein; John Wiloy and Sons, Now Yort, 1974.

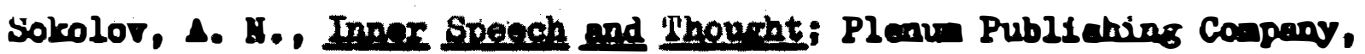
Hor Yort, 1972.

Sperling, George, $\triangle$ codel for viaual neeory tanes, I. Human Fectora Soc., $1963.5,19-36$

Tulving, B., ed., Organtention of Kenory; Acadomic Prese, New Yoric, 1972.

Hesoa, P. C. and Jobnson-Laird, P. M., Percholory of Reasoning; Hervard

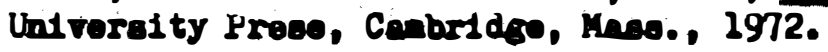




\section{APPEDIX 1}

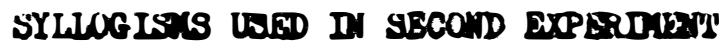

The folloylng aro tho sylloglen wo usad in tho second expartant, tho diffloulty reting, and tho ordar a dotorinod by Gollernan serrea Vubor 10.

1. Sound - Hard - It abould bo a ontral principle of Amorican pollt1ca to arold any polloy which ay land this country in a war which is not in defense of our owe Fital intoroste. An entengleaent in solan intornational politica will lead to the neocealty for flehting waro in whtch no oescatial Merican intervet is at otake. So, Americe ought to avold any oomitaents in Aaten inter nationel apfaire.

2. Sound - Middle - Ho Bolshovike aro 1deallete. All Bolahoviks aro Rusatans. T'borafore, coso Runateno aro not 1dealiste.

3. Unsound - thard - Ono enjor factor which must be taken into account in conaldering the tranafer of territory fron one oountry to another 18 the wabes of the majorlty of the in habltants of the territory in quostion. Thore 18 no doubt that the anjority of the 10habltants of tho Gasa district want thols tarritory to be tranoferred row Iareol to Epopt. Tharofore, it is Ifght that tho tranafer of tho Gasa dietrlet froe Iarael to Eeppt abould take place.

4. Unsound - Pang - Slavery wa an lnofflclent form of labor because of tho lack of Incentive to Individun offort. I alnthar leck of inoantive 18 an ineritable consequence of connaio. or soc1al1o. So, ce vinto and cocialio are, in effeot, forme of elavery.

5. Unsound - Ray - Wheover we noot a ans without personal enbition, we find that bo 18 froe froe that arrognes of ennoer 
which 10 a unpleasant charactorlatic of son oucceseful people. Some of the dictatore aleo ahow this de1Lehtful characteriatic of freodor from arroganco. SO, wo nay conolude that sono dictatore are without perconal abition.

6. Solvd - Hand - Howerer ardently wo no bollere in froodor, wo nust adit the rebt and duty of erary country to lindt

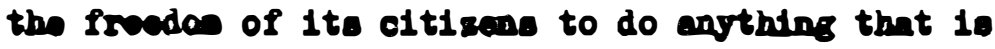
hariul to theanelvoe. It nut aleo bo adritted that

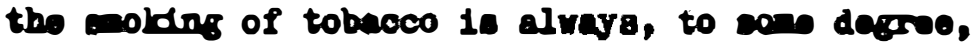
hnsilu. It follows that we mut adint tho rightnase of the total prohibition by law of the alding of tobsoco.

7. Sound - Bad - Staxy wasen 10 a potantial nother, and no one poseesalng this sacred potentiality 10 capable of co:m 1tting arpes of tho roret dind. It followe tiren this that none of the woret orlatnale are vomen.

8. Uncound - Hard - Mnorzen enterpryser cannot develop profitably in South Morica unleas South Anorlea's ow resouroes aro doreloped. Tho oubjugation of South Nerlca by Cuwould rooult in the speedy dovelop ant of South $N$ ortea's resources. Thorafore, the Cubn conquast of South Marice would bo of profit to Mnorlonn anterprisen in South Merras.

9. Sound - Bay - Ho an can be blaned for any ahracteriotic vith which bo was bose or for any consequences of suah a charectarlatic. Som mee aro crintenle bocause thar rore bors with orinloal obaractorlotice. So it followe that cono crininale aro not to be blened for beIng crininals.

10. Unsound - Itddle - It 10 olateod that Commundo he brought prosperity to the countried that have adopted 1t. But thare aro 
thousande who aro walting to enlerete from Rusoia when thoy got tho chance. We any be oure that no one would with to enferete from a prosperous country, 80 wo ny conolude that any stories we ny boar of the proeperity of a Coneuniet country aro nythicel. 


\section{NPPEDIX 2}

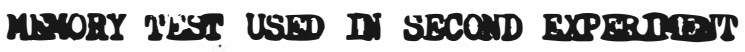

Tho following are tho parte of the adx aylloden that we uad in the enosy toot in tho esooud expersont.

1. ,It abould be a ocatral principle of 4 sorionn politice to avold any fpollog which ing land this coumtry in a. war which is not in defonse of our own vital intereats.

2. 2'horafore, it is right that tho tranefor of the Gaze district fron Ioreol to kopt abould taice place.

3. A alnilnr leak of incentive 1s an inoritable consequence of comumien or coolal1a.

4. It follows that we nust adnt the richtness of the total probibition by lav of the enoleding of tobacco.

5. Anerican catorprises cannot develop profitably in South Anorica unlese South Anorica's own resourcen are doveloped.

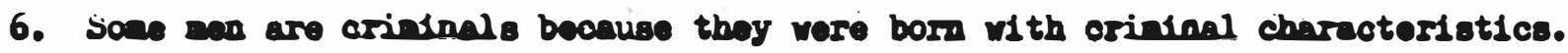

